\title{
Effect of Organic Fertilizer and Microbial Consortium on Growth and Quality Parameters of Gerbera Cv. Red gem and on Soil Health
}

\author{
Luna Barooah Madhumita* and Choudhury Talukdar \\ Department of Horticulture, Assam Agricultural University, \\ Jorhat-785013, Assam, India \\ *Corresponding author
}

\section{Keywords}

Biofertilizers, groundwater, organic flowers, soil fertility

Article Info

Accepted:

14 August 2019 Available Online: 10 September 2019

\section{A B S T R A C T}

A field study was conducted in the Experimental Farm, Department of Horticulture, Assam Agricultural University, Jorhat for three years viz., during 2009-10, 2010-11 and 2011-12. The results of three years pooled data of the experiment revealed that among the different treatments, application of enrich compost@10t/ha $\left(T_{2}\right)$ significantly increases the growth and flower characters followed by combination of enrich compost @ 10t/ha + Biofertilizer $\left(\mathrm{T}_{4}\right)$. Highest plant height $(53.19 \mathrm{~cm})$ stalk length $(56.50 \mathrm{~cm})$, days to full bloom (64.50), no of flowers/Plant (38.19), size of flower $(9.53 \mathrm{~cm})$, self life (21.98 days) vaselife (9.89days) no of suckers/ plant (16.69), benefit cost ratio (7.55) was recorded under treatment $\mathrm{T}_{2}$

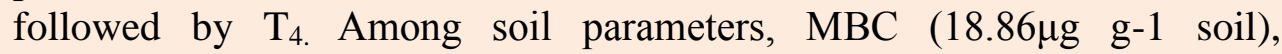
dehydrogenase (264.73 $\mu \mathrm{g}$ TPF g-1 soil), phosphomonoesterase $(42.87 \mu \mathrm{g}$ p-nitophenol g-1 soil), fluorescein diacetate (5.42 $\mu \mathrm{g}$ fluorescein $\mathrm{g}-1$ soil), were found better in treatment treated with enriched compost@10t/ha.

\section{Introduction}

Gerbera (Gerbera gamesonii Bolus) is one of the important commercial cut flower of the world belongs to the family Asteraceae (Compositae). It is native of South Africa and is known as African daisy, Transvaal daisy and Barbeton daisy. Gerbera can be grown in open as well as in protected conditions. Gerbera variety, Red Gem is found suitable for cultivation in open field of Assam. For successful cultivation nutrient management is of prime importance to obtain good quality flower. Organic flowers, according to many people, are more fragrant and last longer than non-organic ones.

The toxic inorganic chemicals used on flower cultivation can poison groundwater and the soil. Adaptation of organic cultivation 
practices for flower production increases the product quality along with its benefits towards a safer ecosystem.

Organic and biofertilizers are cost effective as compared to chemical fertilizers and are ecofriendly. Biofertilizers are the materials which contain living micro organisms which on application to soil mobilize the availability of nutrients by their biological activity. They also provide residual effect for subsequent crops and help in recycling and decomposition of organic matter. Biofertilizers increase crop yield by $20-30 \%$, improve quality of produce, activate soil biologically and restore natural soil fertility. Keeping these points in mind, the present experiment was undertaken to find out the effect of organic fertilizer and biofertilizer on growth and quality parameters of gerbera.

\section{Materials and Methods}

The experiment was conducted for three years viz., during 2009-10, 2010-11 and 2011-12. The soil was sandy loam with $\mathrm{P}^{\mathrm{H}}$ of 4.90 ; organic carbon content 0.64 per cent, available $\mathrm{N} 0.07$ per cent and available $\mathrm{P}_{2} \mathrm{O}_{5}$ and $\mathrm{K}_{2} \mathrm{O}$ was 47.52 and $74.25 \mathrm{~kg}$ per hectare, respectively. The experiment was laid out in randomized block design with three replications. The treatments include $\mathrm{T}_{1}$ : Optimal compost @10t/ha, T $\mathrm{T}_{2}$ : Enrich compost @10t/ha, T3: Optimal compost @ 10t/ha +Biofertilizer, $\mathrm{T}_{4}$ : Enrich compost @ 10t/ha + Biofertilizer, T 5 : Optimal compost @ 5t/ha+Biofertilizer, $\mathrm{T}_{6}$ : Enrich compost @ 5t/ha+ Biofertilizer, $\mathrm{T}_{7}$ : Biofertilizer and $\mathrm{T}_{8}$ : Control. Observations were recorded on plant height, number of leaves, leaf area, and days to first flower emergence, number of days to full bloom, number of flowers, self life of flowers and vase life of cut flowers. Soil microbial biomass carbon (MBC) was determined using the chloroformfumigation- extraction method following the method of Vance et al., (1987). The
DHD activities were determined by the reduction of triphenyltetrazolium chloride (TTC) to triphenylformazan (TPF) as described by Casida et al., (1964) with modifications. Tabatabi and Bremner (1969) method is followed to estimate the Phosphomonoesterase (PMEase) activity.

\section{Results and Discussion}

\section{Growth and flowering parameters}

The growth parameters showed significant difference due to application of different bio and organic fertilizers. The treatment $\mathrm{T}_{2}$ : Enrich compost @10t/ha has recorded highest parameters like plant height $(53.19 \mathrm{~cm})$, Number of leaves per plant(52nos), stalk length $(56.50 \mathrm{~cm})$, suckers per plant(16.67 nos) which was followed by $\mathrm{T}_{4}$ : Enrich compost @10t/ha + Biofertilizer.

Minimum was recorded in treatment $\left(\mathrm{T}_{0}\right)$ control as evident from table no.1. The increase in growth parameters in the treatment $\mathrm{T}_{2}$ is due to the beneficial effect of enriched compost. This may due to increased absorption of nutrients which resulted increase in the synthesis of carbohydrates, hormones activity produced by Azospirillum and PSB which are present in enriched compost. PSB might have increased phosphate availability in the soils which in turn helped better proliferation of root growth and helps to uptake other nutrients. Similarly, flowering parameters like number of flowers per plant (38.19), size of flower $(9.54 \mathrm{~cm})$, self life (21.98 days), vase life (9.89 days) were also higher under $\mathrm{T}_{2}$ followed by $\mathrm{T}_{4}$. Lowest was recorded under control $\left(\mathrm{T}_{0}\right)$ respectively. The treatment $\mathrm{T}_{2}$ recorded the lowest days to full bloom (64.50 days) while highest days for full bloom were recorded under $\mathrm{T}_{0}$. Similar findings were reported by Raha (2015) where the use of organic amendments enhanced the growth and flowering of chrysanthemum. 
Table.1 Effect of organic and bio-fertilizer on growth characters of gerbera (Pooled data over 3 years -2009-10, 2010-11, 2011-12)

\begin{tabular}{|c|c|c|c|c|}
\hline Treatment & $\begin{array}{l}\text { Plant height } \\
\text { (cm) }\end{array}$ & $\begin{array}{l}\text { No of } \\
\text { leaves/ } \\
\text { plant }\end{array}$ & $\begin{array}{l}\text { Stalk } \\
\text { length }(\mathrm{cm})\end{array}$ & $\begin{array}{c}\text { Suckers / } \\
\text { plant }\end{array}$ \\
\hline $\mathrm{T}_{1}(\mathrm{OC} 10 \mathrm{t} / \mathrm{ha})$ & 40.90 & 44.66 & 43.50 & 13.66 \\
\hline $\mathbf{T}_{2}(\mathrm{EC} 10 \mathrm{t} / \mathrm{ha})$ & 53.19 & 52.00 & 56.50 & 16.67 \\
\hline$T_{3}\left(T_{1}+\right.$ Biofet $)$ & 40.68 & 42.66 & 41.83 & 14.77 \\
\hline$T_{4}\left(T_{2}+\right.$ Biofert $)$ & 50.77 & 49.00 & 51.00 & 14.99 \\
\hline $\begin{array}{l}T_{5}(\text { OC } 5 \\
\text { t/ha+Biofert })\end{array}$ & 39.60 & 37.66 & 41.50 & 13.33 \\
\hline $\begin{array}{l}T_{6}(\text { EC } 5 \\
\text { t/ha+Biofert })\end{array}$ & 41.26 & 44.33 & 42.00 & 14.11 \\
\hline$T_{7}$ (Biofert) & 38.65 & 37.66 & 40.83 & 12.33 \\
\hline $\mathbf{T}_{8}($ Control $)$ & 37.28 & 33.66 & 38.00 & 11.89 \\
\hline CD $5 \%$ & 0.99 & 3.38 & 0.69 & 0.59 \\
\hline
\end{tabular}

Table.2 Effect of bio-fertilizer on flowering of gerbera (Pooled data over 3 years -2009-10, 2010-11, 2011-12)

\begin{tabular}{|l|l|c|c|c|}
\hline Treatments & $\begin{array}{l}\text { Days to full } \\
\text { bloom }\end{array}$ & $\begin{array}{c}\text { No. of } \\
\text { flower/ plant }\end{array}$ & $\begin{array}{c}\text { Size of flower } \\
\text { (cm) }\end{array}$ & $\begin{array}{c}\text { Vase life } \\
\text { (Days) }\end{array}$ \\
\hline $\mathbf{T}_{\mathbf{1}}$ (OC 10 t/ha) & 69.93 & 24.92 & 8.34 & $\mathbf{6 . 8 7}$ \\
\hline $\mathbf{T}_{\mathbf{2}}$ (EC 10 t/ha) & 64.50 & 38.19 & 9.53 & $\mathbf{9 . 8 9}$ \\
\hline $\mathbf{T}_{\mathbf{3}}\left(\mathbf{T}_{\mathbf{1}}+\right.$ Biofet) & 71.00 & 25.50 & 8.23 & $\mathbf{7 . 2 8}$ \\
\hline $\mathbf{T}_{\mathbf{4}}\left(\mathbf{T}_{\mathbf{2}}+\right.$ Biofert) & 67.73 & 36.88 & 9.14 & $\mathbf{8 . 6 7}$ \\
\hline $\begin{array}{l}\mathbf{T}_{\mathbf{5}}(\mathbf{O C ~ 5} \\
\text { t/ha+Biofert) }\end{array}$ & 70.36 & 27.05 & 7.61 & $\mathbf{7 . 6 3}$ \\
\hline $\begin{array}{l}\mathbf{T}_{\mathbf{6}} \text { (EC 5 } \\
\text { t/ha+Biofert) }\end{array}$ & 71.00 & 26.12 & 8.40 & $\mathbf{7 . 0 3}$ \\
\hline $\mathbf{T}_{\mathbf{7}}$ (Biofert) & 68.53 & 25.01 & 8.13 & $\mathbf{6 . 6 4}$ \\
\hline $\mathbf{T}_{\mathbf{8}}$ (Control) & 74.73 & 22.59 & 8.42 & $\mathbf{6 . 5 3}$ \\
\hline CD5\% & $\mathbf{5 . 5 8}$ & $\mathbf{0 . 3 8}$ & $\mathbf{0 . 3 5}$ & $\mathbf{6 . 8 7}$ \\
\hline
\end{tabular}


Table.3 Effect on microbial population and soil health parameters

\begin{tabular}{|c|c|c|c|c|}
\hline Treatments & $\begin{array}{c}\mathrm{MBC} \\
\left(\mu \mathrm{g}^{-1}\right)\end{array}$ & $\begin{array}{l}\text { Dehydrogenase } \\
\left(\mu \mathrm{g} \text { TPF } \mathrm{g}^{-1}\right. \\
\left.24 \mathrm{~h}^{-1}\right)\end{array}$ & $\begin{array}{l}\text { Phosphomonoesterase } \\
\text { (PMEase) activity ( } \mu \mathrm{g} \\
\text { p-nitrophenol g-1 soil } \\
\text { hour-1) }\end{array}$ & $\begin{array}{l}\text { Fluorescein Di- } \\
\text { acetate Hydrolysis } \\
\text { (FDA) activity }(\mu g \\
\text { fluorescein g-1 soil } \\
\text { hour-1) }\end{array}$ \\
\hline $\mathrm{T}_{1}(\mathrm{OC} 10 \mathrm{t} / \mathrm{ha})$ & 436.84 & 128.89 & 48.78 & 4.8 \\
\hline $\mathrm{T}_{2}(\mathrm{EC} 10 \mathrm{t} / \mathrm{ha})$ & 498.86 & 264.73 & 42.87 & 5.42 \\
\hline$T_{3}\left(T_{1}+\right.$ Biofet $)$ & 415.14 & 154.26 & 52.26 & 6.39 \\
\hline$T_{4}\left(T_{2}+\right.$ Biofert $)$ & 472.91 & 245.00 & 42.64 & 6.43 \\
\hline$T_{5}($ OC 5 t/ha+Biofert $)$ & 326.05 & 110.86 & 44.52 & 5.53 \\
\hline$T_{6}($ EC 5 t/ha+Biofert $)$ & 362.22 & 229.57 & 52.00 & 5.72 \\
\hline $\mathbf{T}_{7}$ (Biofert) & 289.42 & 127.03 & 64.66 & 7.58 \\
\hline$T_{8}$ (Control) & 244.06 & 102.34 & 36.32 & 8.57 \\
\hline CD at $5 \%$ & 12.67 & 16.06 & 2.37 & 0.82 \\
\hline
\end{tabular}

The induction of earliness was due to better nutritional status of the soil which ultimately increases the nutritional status of the plants. Naik et al., (2006) reported that in gerbera, greater leaf area, more number of leaves per plant and plant spread increases which in turn resulted in production of more number of flowers.

\section{Soil health parameters}

Soil health parameters like microbial biomass carbon, dehydrogenase activity was found higher under $\mathrm{T}_{2}$ followed by $\mathrm{T}_{4}$. Enriched compost resulted in the highest MBC (226.39 $\mu \mathrm{g} / \mathrm{g}$ soil) than the control $(99.44 \mu \mathrm{g} / \mathrm{g}$ soil). This might be due to higher availability of substrate as carbon from applied organic source of nutrients which improved microbial and enzymatic activities in soil (Rajkonwar, 2012). Increased microbial biomass resulting from continuous organic matter enrichment in soil, since addition of good quality compost had a direct bearing on microbial biomass and soil enzyme activities (Albiach et al., 2000). Walia et al., 2004 also reported that microbial biomass carbon was more with organic farming treatment and showed higher activity of dehydrogenase and phosphatase activity.

The dehydrogenase activity in the present study increased significantly in soils under treatment T2 (270.70 $\mu \mathrm{g}$ TPF g-1 soil $24 \mathrm{hr}-1)$. Enrich compost may possibly provide microbial diversity and activity of micro organisms which in turn resulted better dehydrogenase activity. Mukherjee et al., 2002 stated that enriched compost nurtured high population of bacteria, actinomycetes fungi, non symbiotic $\mathrm{N}$ fixing bacteria and PSB. Application of enriched compost resulted significantly higher phosphomonoesterase activity (374.22 $\mu \mathrm{g} p$-nitrophenol g-1 soil $\mathrm{h}-1$ ). This may be due to release of more organically bound $\mathrm{P}$, as synthesis of enzyme is stimulated by the presence of organic substrate (Biswas and Narayanswamy, 2006). Fluorescein di-acetate hydrolysis is showing highest value in enriched compost $(5.42 \mu \mathrm{g}$ fluorescein $\mathrm{g}_{-1}$ soil $\mathrm{h}-1$ ). This could be attributed to increased microbial biomass resulting from continuous organic matter enrichment in soil which has a beneficial effect on microbial biomass and soil enzyme activities. This is in conformity with Chang et al., (2007). Highest PMEase activity of 
63.76 $\mu \mathrm{g}$ p-nitrophenol g-1 soil hour-1 under the soil treated with treatment T8 (Enriched compost 5t ha-1). Rock phosphate carrying enriched compost could have augmented the available phosphate in the treatment. It may be due to the release of more organically bound phosphate as a result of synthesis of enzyme which is stimulated by the presence of organic substrate (Biswas and Narayanaswamy, 2006).

Sanwal et al., 2007 reported that application of organic fertilizer not only produced higher and sustainable crop yield, but also improved soil fertility and productivity. Organic manure has beneficial effect on physical, chemical and biological characteristics of soil, which in turn influences growth and productivity of plant (Molla et al., 2005). Biswas et al., 2008 revealed that application of enrich compost increases soil organic carbon content, available $\mathrm{N}, \mathrm{P}$ and $\mathrm{K}$ in soil.

From the above experiment, it was evident that organic fertilizer and microbial consortium had positive impact on yield, quality of gerbera as well as on soil health. Among the different treatments, $T_{2}$ (Enriched compost 10t ha-1) was found to be best.

\section{References}

Albiach, R., Canet, R., Pomares, F. and Ingelmo, F. (2000). Microbial biomass content and enzymatic activities after the application of organic amendments to a horticultural soil. Bioresour.Technol. 75 : $43-48$.

Biswas, D. R. and Narayanasamy, G. (2006). Rock phosphate enriched compost: An approach to improve low grade Indian rock phosphate. Bioresour. Technol. 97: 224351.

Casida, L E ; Klein D. A and Santoro, R (1964): Soil dehydrogenase activity. Soil Science: 98 : 371-376

Chang, E., Chung, R. and Tsai, Y. (2007).
Effect of different application rates of organic fertilizer on soil enzyme activity and microbial population. Soil Sci. and Pl. Nutri. 53(2): 132-140

Danish R; Srinivasan, V; Hamza, S and Manjusha, A (2010). Short term incorporation of organic manures and biofertilizers influences biochemical and microbial characters of soil. Biores Technol. 101: 4697-4702

Molla, AH; Fakhrul Razi, A, Hanafi, M M ; Alam, M. Z (2005). Compost produced by solid state bio-conservation of biosolids: A potential source for plant growth and environment friendly disposal. Commercial Soil Sci. Plant Analysis 36: 1435-1444

Mukherjee, D; Das S; Saha N; Sahu, S. S; Chakraborty, A; Halder, M ; Bhattacharyya $\mathrm{K}$ and Mukhopadhyay, $\mathrm{N}$ (2002). Microbial changes during the process of composting. In: International Conference on managing natural resources for sustainable agricultural production in $21^{\text {st }}$ Century Extd Sum 2: $712-714$

Nath, R and Samanta, R(2012).Soil PH, microbial population, nitrate reductase and alkaline phosphatase activities of different environment of dibrugarh district, Assam. Adv. Appl Sci Res. 3(3): 1772-1775

Naik, B.H., N. Chauhan, A.A. Patil, V.S. Patil and B.C. Patil. 2006. Comparative performance of gerbera cultivars under naturally ventilated polyhouse. Journal of Ornamental Horticulture, 9: 204-207.

Raha, S. 2015. Studies on the effect of vermicompost on the growth, yield and quality of hrysanthemum (Chrysanthemum coronarium L. cv. Kasturba Gandhi). International Journal of Environmental Science, 4(2): 68-71.

Rajkonwar, U. (2012). Assessment of organic sources on microbial biomass and nutrient availability in tea soil. M.Sc. 
(Agri.) Thesis. Assam Agricultural University, Jorhat.

Sanwas, SK; Lakminarayana, $\mathrm{K}$ and Yadav R.K ; Rai N; Yadav, D.S and Mousumi, $B(2007)$. Effect of organic manure on soil fertility, growth, yield and quality of turmeric. Ind. J.Hort. 64:444-449

Subhani, A., Changyong, H., Zhengmiao, X., Min, L. and El-Ghamry, A. M. (2001). Impact of soil environment and agronomic practices on microbial/dehydrogenase enzyme activity in soil-A review. Pak. J. Biol. Sci. 4 : 333-38.
Walia, S. S ; Kler, D. S ; Gill, M. S(2004). Soil microflora as influenced by organic and inorganic sources of nutrition in maize wheat system. In: Proc. $2^{\text {nd }}$ National Symposium on Alternate farming system held at Project Directorate of cropping system research, Modipuram, Meerut $16^{\text {th }}$ to $18^{\text {th }}$ SeptemberPP:166-168

Vance, E D; Brookers, P. C and Jenkinson, D. $S$ (1987). An extraction method for measuring soil microbial biomass carbon. Soil Biology and Biochemistry 19: 703-707.

\section{How to cite this article:}

Luna Barooah Madhumita and Choudhury Talukdar 2019. Effect of Organic Fertilizer and Microbial Consortium on Growth and Quality Parameters of Gerbera Cv. Red gem and on Soil Health. Int.J.Curr.Microbiol.App.Sci. 8(09): 1176-1181. doi: https://doi.org/10.20546/ijcmas.2019.809.134 